\title{
Analisis Framing Berita Penembakan 6 Laskar FPI Pada Portal Berita Online CNN Indonesia Periode 19 Februari - 03 Maret 2021
}

\author{
${ }^{1}$ Zahrina Nurfadillah, ${ }^{2}$ Mulia Ardi \\ UIN Sayyid Ali Rahmatullah Tulungagung \\ 'zahrina.nf27@gmail.com, ${ }^{2}$ mulia.ardi@gmail.com
}

\begin{abstract}
ABSTRAK
Media berperan sentral pada masyarakat saat ini. Namun tanpa disadari, bahwa kebutuhan pada media berpengaruh terhadap bagaimana media tersebut melakukan sebuah framing pada suatu berita. Analisis framing digunakan untuk mengetahui bagaimana perspektif isu oleh media ketika melakukan penyeleseksian isu dan menentukan fakta yang akan digunakan, dan bagian mana yang akan ditonjolkan. Penelitian ini memiliki tujuan untuk mengetahui bagaimana CNN Indonesia membingkai kasus penembakan 6 Laskar FPI. Metode penelitian yang digunakan adalah pendekatan kualitatif deskriptif dengan metode analisis framing Zhongdang Pan Kosicki. Hasil penelitian menunjukan bahwa unsur-unsur analisis framing Zhongdang Pan terepresentasi pada pemberitaan CNN Indonesia. Unsur-unsur tersebut antara lain, sintaksis, skrip, tematik dan retoris. CNN Indonesia tidak menggiring pembaca untuk memihak atau condong kepada salah satu pihak, tetapi membiarkan pembaca untuk melakukan pembentukan pandangan sendiri terhadap peristiwa yang di informasikannya.
\end{abstract}

\section{Kata Kunci : Analisis Framing, Berita, CNN Indonesia}

\begin{abstract}
The media plays a central role in today's society. But unwittingly, that need in the media affects how the media does a framing on a news. Framing analysis is used to find out how the perspective of the issue by the media when performing the issue correction and determining the facts to be used, and which parts will be highlighted. This study aims to find out how CNN Indonesia framed the shooting of 6 FPI Warriors. The research method used is descriptive qualitative approach with Zhongdang Pan Kosicki framing analysis method. The results showed that elements of Zhongdang Pan framing analysis were presented in CNN Indonesia news. These elements include syntax, scripts, thematics and rhetoric. CNN Indonesia does not encourage readers to side or lean towards either party, but allows the reader to make his own views on the events he informs.
\end{abstract}

Keywords: Framing Analysis, News, CNN Indonesia 


\section{PENDAHULUAN}

Pada bulan Desember 2020 beberapa media massa di Indonesia memberitakan mengenai penembakan 6 laskar FPI di Jalan Tol Jakarta-Cikampek KM 50. Aksi tersebut dilakukan oleh anggota polisi dan laskar fpi (CNN.Indonesia). Beberapa kali media telah mempublikasikan kasus serupa. Misalnya pada 6 Oktober 2008, media online memberitakan bahwa anggota Kepolisian Lampung ditembak yang menyebabkan luka-luka pada seorang warga sipil di Lampung, Sumatera Selatan. Berikut merupakan judul dari pemberitaan tersebut "Polisi Main Tembak Ditindak Tegas" di Lampung (Nonik Wahyu, 2013). Kasus terbaru mengenai penembakan yang dilakukan oleh oknum kepolisian kembali terjadi pada 26 Februari 2021, media online Kompas.com dengan headline berita "Detik-detik Polisi Mabuk Tembak TNI dan Pegawai di Cafe RM, Saksi: Orang-orang Keluar dengan Menangis (Kompas.com). Media massa merupakan sarana penyebarluasan informasi kepada khaIayak Iuas, media massa juga diartikan sebagai media yang menyebarkan informasi kepada publik dan dapat diakses secara luas oleh masyarakat. Dalam menyampaikan informasi berupa pemberitaan antar media, media lain memiliki perbedaan tersendiri. Perbedaan ini dipengaruhi oleh latar belakang para reporter media (Bungin, 2006).

Cahrnley pada Effendy (2003) mengartikan beerita merupakan laporan tercepat bagi kebanyakan orang yang memuat suatu fakta dan opini, yang mengandung hal-hal yang menarik dan penting, ataupun keduanya. Penelitian terdahulu yang memiliki kesamaan yaitu dilakukan oleh Primawati (2011) membahas tentang hasil pemberitaan kejahatan polisi di media massa dan pembentukan opini publik tentang citra polisi. Sedangkan Nitasari (2006) membahas pandangan aparat kepolisian dan masyarakat tentang penerapan paradigma baru kepolisian. Kedua penelitian ini memiliki kemiripan dengan penelitian ini karena menggunakan tema yang sama yaitu kepolisian dan masalah sosial. Perbedaannya adalah peneliti menggunakan analisis framing sebagai metode penelitian penyampaian fakta secara aktual dalam suatu berita agar tidak menimbulkan provokasi dimasyarakat.

Media berfungsi sentral pada masyarakat. Lewat media, data, pemikiran, gagasan serta wacana silih dipertukarkan serta kemajuan warga pula tercermin di dalamnya. Pada masyarakat modern, media tertanam secara mendalam di kehidupan sosial (Alex Sobur. 2015). Berita merupakan infromasi yang bisa dikatakan dikonsumsi setiap harinya di masyarakat, karena berita didapatkan dari hasiI kegiatan pemberitaan, sehinga beritapun berdampak pada pembentukan opini masyarakat. Baru-baru ini, konsep framing sudah banyak digunakan dalam literatur ilmu komunikasi dalam mendeskripsikan proses pemilihan media serta menekankan aspek tertentu dari kenyataan (Alex Sobur. 2015). Dalam penelitian ini anaIisis framing digunakan untuk menilik portal berita online CNN Indonesia yang memberitakan penembakan 6 laskar FPI. Berita tersebut hangat dibincangkan oleh 
masyarakat karena banyaknya perbedaan yang disampaikan dari berbagai media yang ada di Indonesia. Cnn Indonesia dipilih karena dirasa sebagai media yang Independen yang dalam menyampaikan beritanya tidak berpihak kepada manapun, transparan, akurat, dan adil (Adolf Hitler, 2019).

Dengan adanya artikel ilmiah ini bertujuan agar dapat menjadi alternatif untuk memaparkan informasi yang lebih detail dan akurat mengenai pengemasan berita pada media dengan mengunakan metode framing. Jika pada pandangan komunikasi, framing digunakan sebagai alat untuk membedah ideologi suatu media dlam mengkonstruksikan fakta (Eriyanto, 1999). CNN (Cable News Network) Indonesia adalah televisi swasta dan stasiun televisi berita yang dimiliki bersama oleh Transmedia dan Turner International. Kehadirannya di Indonesia diharapkan dapat menjadi sumber informasi yang berkualitas dan obyektif bagi masyarakat Indonesia dalam pemberitaan nasional dan internasional. Hal ini sesuai dengan filosofi CNN Indonesia yaitu "Indonesian version of CNN, in Indonesian, Owned by Indonesia, Made by Indonesian Journalist, for Indonesia and the world (Adolf Hitler, 2019). Untuk mengetahui bagaimana portal berita online CNN.Indonesia membingkai pemberitaan mengenai kasus penembakan 6 laskar FPI dengan menggunakan model analisis framing Zhong Dan Pan dan Gerald M. Kosicki.

\section{METODE PENELITIAN}

Jenis penelitian ini yaitu pendekatan kualitatif deskriptif mengunakan metode analisis framing. Karena dalam penelitian ini memerlukan data yang berupa informasi deskriptif (Subandi, 2011). Subjek yang digunakan adalah portal berita online CNN Indonesia. Sedangkan objeknya menggunakan teks berita pada CNN Indonesia mengenai penembakan 6 laskar FPI periode 19 Februari 2021-03 Maret 2021. Periode tersebut dijadikan pilihan karena merupakan periode dilakukannya peneIitian sehinga di harapkan akan dapat membantu bagi khalayak pembaca karena kebaharuan datanya. Teknik pengumpulan datanya menggunakan teknik dokumentasi dan kepustakaan yaitu dengan mengumpulkan data berupa berita, dilengkapi dengan judul dan tanggal berita dengan harapan data akan Iebih valid. Data primer penelitian iini adalah portal berita online CNN Indonesia dan sekunder nya berupa artikel ilmiah, buku, internet dan dokumen yang memiliki korelasi dengan objek penelitian tersebut. Teknik analisis data yang digunakan yaitu analisis framing, mengacu kepada model Zhongdang Pan Kosicki. Model ini menggunakan model pendekatan sintaksis, skrip, tematik, dan retoris (Eriyanto, 2002). Sehingga lebih tepat menggunakan model ini karena model yaang digunakan serta Pan dan Kosicki dapat memberikan penjabaran yang mendalam untuk melihat pembingkaian suatu berita (Maulidatus, 2020). 


\section{HASIL DAN PEMBAHASAN}

Framing Berhubungan dengan bagaimana realitas dibingkai dan disuguhkan kepada khalayak (Eriyanto, 2002). Analisis Framing memiliki empat model yang dikembangkan oleh para ahli diantaranya yaitu model Robert N. Entman, William A. Gamson, M. Edelman dan Zhongdang Pan dan M. Kosicki. Konsep framing dipakai untuk membedah tahapan-tahapan atau ideologi yang tertanam pada media dalam melakukan penyeleksian, menonjolkan, dan pertautan fakta ke dalam berita agar memiliki makna mendalam(Azwar, 2016). Media melakukan tahapan tersebut karena khalayak bukan disuguhkan dengan informasi mentah sehingga sulit untuk dipahami, tetapi menyajikan informasi yang mudah dimengerti agar lebih diketahui dan lebih diingat (Eriyanto, 2002).

Berita merupakan produk konstruksi sosial media massa yang cukup rentan untuk dimanipulasi, sehingga ada kemungkinan untuk selalu berbeda dengan kepentingan media itu sendiri (Krisna, 2012). Media bisa mengkonstruksikan suatu fakta, namun juga bisa menghadirkan fakta yang berlebihian (Alex Sobur, 2015). Setiap media memiliki gaya masing-masing untuk melakukan penkontrusian berita, perlu ditekankan bahwa media bukan saluran yang bebas tetapi telah mengkonstruksi berita sedemikian rupa. Disimpulkan bahwa setiap media dapat meninformasikan berita dengan tema yang sama, tetapi dengan cara pandang yang berbeda (Tari Suprobo, 2014).

Menurut Zhongdang Pan Kosicki (Eriyanto, 2002), ada dua konsep dari framing yang saling berkaitan. Pertama yaitu konsepsi psikologi, dimana framing berkaitan dengan struktur dan proses pengetahuan faktual, bagaimana seseorang mengolah berbagai macam informasi dan ditunjukkan menuju skema tertentu. Kedua konsepsi sosiologis, frame disini berfungsi membuat suatu realitas menjadi diketahui, dipahami, dan dimengerti oleh dirinya dan realitas di luar dirinya. Kedua konsep tersebut bisa dilihat dari bagaimana suatu kabar dibuat serta peristiwa di kontruksi oleh wartawan. Penelitian ini menggunakan analisis framing Zhongdang Pan Kosicki. Adapun perangkat framing dibagi menjadi 4 struktur besar (Eriyanto,2002) :

\section{Struktur Sintaksis}

Sintaksis merupakan susunan kata atau frase dalam suatu kalimat. Dalam wacana berita, sintaksiis menunjuk pada pengertian susunan dan bagian berita, yaitu headline, lead, latar informasi, sumber, dan penutup. Dalam hal ini, bentuk sintaksis yang paling popular adalah struktr piramida terbalik. Struktur tersebut dimulai dari headline, lead, episode, latar, dan penutup.

\section{Skrip}

Bentuk umum dari struktrur skrip yaitu pola $5 \mathrm{~W}+1 \mathrm{H}$. Adapun pola ini terdiri dari Who, When,What,Where,Why, dan How. Walaupun pola ini tidak selalu dapat ditemui pada setiap berita yang diinformasikan, kategori informasi yang diharapkan oeleh wartawan untuk disampaikan kepada khalayak. 


\section{Tematik}

Menurut Pan dan Kosicki, berita mirip dengan pengujian hipotesis yaitu peristiwa yang diliput dan penyataan yang diungkapkan. Struktur Tematik adalah cara pandang wartawan terhadap suatu peristiwa yang terjadi kedalam proposisi, kalimat, atau hubungan antar kalimat yang membentuk suatu teks secara keseluruhan. Struktur tematik juga berhubungan dengan bagaimana wartawan menulis fakta kedalam berita.

\section{Retoris}

Struktur retoris dalam berita menggambaarkan piilihan gaya atau kata yang dipilih oleh wartawan untuk menekankan pesan yang ingin disampaikan pada berita tersebut. Wartawan menggunakan perangkat retoris untuk menciptakan citra, menonjolkan pada sisi terntu dalam berita, dan meningkatkan gambaran yang diinginkan dari berita tersebut.

Analisis pembingkaian ini dilakukan kepada pemberitaan penembakan 6 Laskar FPI pada portal berita online CNN Indonesia Periode 19 Februari 2021-03 Maret 2021.

\section{Analisis Berita 1}

Judul : Kabareskrim Baru Agus Andrianto Jamin Kasus KM 50 Tuntas

Keterangan : Jum'at 19 Juni 2021/ 14.41 WIB

Analisis :

Sintaksis

Lead diawali dengan memperlihatkan penegasan janji dari Komjen Agus Andrianto akan menyelesaikan masalah besar yang menjadi perhatian publik salah satunya kasus dengan polisi dan laskar FPI di tol JakartaCikampek. Kutipan yang diambil dalam penulisan berita ini yakni dari Komjen Agus Andrianto sebagai calon Kepala Bareskrim, Kapolri, dan Komnas HAM.

Skrip

Berita ini lebih menonjolkan kepada aspek siapa (who). Yakni sosok Agus Andrianto yang menjanjikan dirinya untuk menyelesaikan kasus tol Cikampek. Kemudian menunjukan penunjukan Agus sebagai Kabareskrim dengan adanya surat keputusan.

Tematik

Susunan diawali dengan sosok Komjen Agus Andrianto yang berjanji untuk menyelesaikan kasus tol Cikampek jika telah resmi dilantik nantinya. Kemudian terdapat narasi yang menghubungkan dengan Kapolri Listyo Sigit Prabowo bahwa ia akan mengikuti kebijakan yang dicanangkan oleh Kapolri. Pada bagian selanjutnya kembali lagi ke penjelasan tentang profil 
Agus yang pernah juga menangani kasus besar. Kemudian ditutup dengan menghubungkan kembali dengan Kapolri Listyo yang mengatakan bahwa sudah ada rekomendasi dari Komnas HAM dalam menyelesaikan kasus penembakan di tol Cikampek. Kemudian bagian akhir ditutup dengan rekomendasi dari Komnas HAM.

Retoris

Penambahan kalimat "bakal menuntaskan" dan "jika sudah resmi dilantik" menunjukan bahwa hal tersebut merupakan sebuah janji yang dibuat untuk menuntaskan kasus penembakan laskar FPI di tol Jakarta-Cikampek.

\section{Analisis Berita 2}

\section{Judul \\ : Kabareskrim Baru Ungkap Ada Kendala Tuntaskan Kasus KM 50}

Keterangan : Rabu, 24 Februari 2021 / 19.43 WIB

Analisis

Sintaksis

Penulisan lead dalam pemberitaan ini menekankan salah satu pihak, yakni pihak Polri. Karena diawali dengan narasi bahwa pihak Polri masih menemukan kendala dalam menangani kasus penembakan di tol Cikampek terhadap laskar FPI. Kemudian kutipan yang digunakan adalah dari Kepala Badan Reserse Kriminal yang membuat pernyataan kepada publik untuk bersabar karena memerlukan waktu. Selain itu, kutipan juga diambil dari Komnas HAM yang menyimpulkan polisi melanggar HAM karena melakukan pembunhan 4 dari 6 laskar FPI tanpa melakukan pencegahan kematian.

Skrip

Penulisan berita ini lebih menekankan pada sisi apa (what) yang terjadi. Hal yang ditetapkan adalah adanya kendala dalam menyelesaikan kasus tersebut tanpa menyertai alasan lengkap (why) tentang kendala yang sedang terjadi atau bagaimana (how) proses yang sudah dilakukan sehingga publik mengetahui keseluruhan kejelasan proses.

Tematik

Penulisan diawali dengan paragraf pembuka sebagai lead yang menunjukkan bahwa proses penanganan kasus masih mengenai kendala. Kemudian pada bagian selanjutnya dijelaskan tentang pernyataan Komnas HAM yang telah merekomendasikan dan menyimpulkan bahwa anggota Polri sudah melakukan pelanggaran HAM sehingga dapat dlanjutkan ke proses penegakan hukum melalui mekanisme pengadilan pidana. Framing yang dibuat dalam pemberitaan ini lebih menekankan atau condong ke salah satu pihak yang telah melakukan kesalahan dilihat dari koherensi antar paragraf. 
Retoris

Pemilihan kalimat "menemukan sejumlah kendala" adalah teknik untuk menunjukan proses yang dilakukan pihak Polri masih belum menuai keterangan yang belum jelas. Makna lain adalah usaha yang dilakukan terkesan sangat lama dan tidak ada keputusan pasti apakah pelaku akan di proses ke tahap selanjutnya atau akan dihentikan bergitu saja tanpa adanya kejelasan.

\section{Analisis Berita 3}

Judul : Keluarga Laskar FPI Undang Kapolda Metro Sumpah Mubahalah

Keterangan : Selasa, 02 Maret 2021/ 09.28 WIB

\section{Analisis}

Sintaksis

Pada unsur sintaksis berita ini penulis berusaha secara langsung menjelaskan dan menggambarkan bahwa adanya konflik antara anggota FPI dan Polri. Dilihat dari penggunaan kalimat "Keluarga korban 6 laskar Front Pembela Islam (FPI) menantang Kapolda Metro Jaya". Telihat pada lead tersebut ada dua pihak yang dan salah satunya mengajukan tantangan.

Dari latar informasi terlihat penggambaran tantangan anggota FPI kepada Polri karena tidak adanya kejelasan dan ketidakpercayaan keluarga korban terkait hasil investigasi mengenai peristiwa penembakan 6 orang anggota FPI di tol Jakarta-Cikampek.

Kutipan yang digunakan berasal dari berbagai pihak tim pengawal peristiwa pembunuhan 6 laskar FPI sebagai pernguat isu penembakan dari pihak korban. Kutipan ini ditunjukan dengan pernyataan secara langsung. Penulis juga memberikan opini sebagai penutup berita dari sudut pandang lain yang berbeda dari lead berita. Opini yang dituliskan merupakan pernyataan dari pihak Komnas HAM yang menyatakan menengahi peristiwa tersebut dengan kalimat "Komnas HAM menyatakan bentrok tidak akan terjadi jika laskar tak menunggu kedatangan polisi.Komnas juga menyatakan penembakan terhadap 4 dari 6 laskar FPI melanggar HAM".

Skrip

Pada elemen skrip alasan (why) menjadi hal yang lebih ditonjolkan dalam penulisan berita ini. Penulis lebih menekankan kepada alasan sumpah mubahalah dilaksanakan. Hal ini dilakukan dengan tujuan memberikan informasi tentang sumpah mubahaah kepada publik terlebih dahulu. Walaupun didalam narasi tersebut sudah pernah dijelaskan bahwa sumpah mubahalah juga pernah diberitakan media ketika Rizieq Sihab menyampaikan sumpah mubahalah saat kasus chat mesum. Selain itu, 
penulis juga tetap menekankan pada unsur siapa (who) seperti yang tergambar pada lead berita, yakni pihak FPI dan Polri.

Tematik

Secara tematik, berita ditulis dengan kalimat awal pihak FPI menantang pihak Polri dengan sumpah mubahalah untuk membuktikan kebenaran pada peristiwa tol Cikampek. Kemudian penulis menjelaskan argumen pendukung dari pihak FPI sebagai alasan sumpah dilakukan. Selain itu, pada pemberitaan ini ditambahkan sebuah infografis "Insiden Penembakan Laskar FPI Versi Komnas HAM" yang berisi temuan pernyataan dari pihak Polri, karena Komnas HAM menyimpulkan peristiwa penembakan kepada laskar FPI sebagai tindak pelanggaran HAM. Dibagian akhir penulis menekankan kembali kilas balik tentang peristiwa penembakan, pernayataan Komnas HAM yang turun tangan mengusut kasus itu, dan menujukan Komnas HAM sebagai penengah kasus teresebut dengan narasi "Komnas HAM menyatakan bentrok tidak akan terjadi jika laskar tak menunggu kedatangan polisi Komnas juga menyatakan penembakan terhadap 4 dari 6 laskar FPI melanggar HAM".

Retoris

Usaha pembingkaian (framing) terlihat pada penggunaan diksi "menantang" yang dapat diartikan untuk mengajak berkelahi. Hal tersebut menegaskan masih ada pembelaan dari pihak korban bahwa hasil yang dipaparkan oleh pihak Polri masih belum disampakan secara benar.

\section{Analisis Berita 4}

\section{Judul : Polri Cari Bukti Permulaan Unlawfull Killing 6 Laskar FPI \\ Keterangan : Rabu, 03 Maret 2021/18.16 WIB \\ Analisis}

Sintaksis

Lead yang digunakan pada berita ini menunjukan kecenderungan tidak ada hubungan dengan isi berita yang akan disampaikan. Penulis hanya sekilas menjelaskan bahwa pihak Polri sudah berkoordinasi dengan Kejaksaan Agung. Sedangkan lead sendiri biasanya mengandung prioritas yang lebih tinggi. Dibuktikan dengan penggunaan kata "terpisah" pada paragraf kedua yang berarti isi yang dibahas sudah berbeda dari sebelumnya.

Sedangkan latar informasi yang digunakan dalam pemberitaan ini diambil dari berbagai permasalahan. Pertama, permasalahan pelaporan atau koordinasi Polri dengan Kejaksaan Agung. Kedua, Kapolri yang memerintahkan agar segera diselesaikan kasusnya dengan rekomendasi Komnas HAM. Dan yang ketiga dari permasalahan keluarga korban Laskar FPI yang menantang Kapolri melakukan sumpah mubahalah. 
Selain itu, kutipan yang digunakan untuk memperkuat argumen dengan mengambil dari pernyataan berbagai pihak yakni Direktur Tindak Pidana Umum Bareskrim Polri, Kapolri, Ketua Tim Pengawal Peristiwa Pembunuhan kematian laskar FPI, Ustaz kegiatan sumpah Mubahalah.

Opini yang dibangun dalam paragraf penjelas tentang berbagai permasalahan membuat lead berita menjadi kabur. Sehingga opini lain yang tidak sesuai dengan lead berita menjadi lebih kuat.

Skrip

Susunan penulisan lebih banyak memberikan isi bagaimana peristiwaperistiwa tentang pengusutan kasus penembakan di tol Cikampek antara Polri dan anggota FPI (how). Proses yang ditunjukan adalah tentang apa yang dilakukan pihak Polri dalam proses mencari kebenaran dalam kasus penembakan ini, yakni berkoordinasi kepada kejaksaan agung. Kemudian proses tentang cara keluarga laskar FPI mencari kebenaran dengan cara meminta pihak kepolisian melakukan sumpah mubahalah.

Tematik

Penulisan berita ditampilkan dengan tidak adanya koherensi antara lead berita dengan paragraf-paragraf pendukung lainnya hingga akhir pemberitaan. Pada awal penyampaian berita, penulis menunjukan hal yang sudah dilakukan pihak Polri yakni berkoordinasi dengan kejaksaan. Kemudian paragraf atau bagian selanjutnya menjelaskan tentang dugaan unlawful killing oleh petugas Polri, dan pada bagian terakhir menjelaskan tentang ketidakhadiran pihak Polri ketika ditantang pihak FPI melakukan sumpah muhabalah. Sehingga framing yang dibentuk dalam pemberitaan ini cenderung menyudutkan pihak Polri.

Retoris

Pemilihan kata "terpisah" sering digunakan dalam permulaan paragraf, sehingga kecenderungan kata tersebut menjadi kata yang sangat mencolok. Kata tersebut digunakan untuk memisah isi antara satu dengan yang lain atau membedakan sesuatu yang dibahas didalamnya.

\section{Analisis Berita 5}

\section{Judul : Ditembak mati, 6 Laskar FPI Jadi Tersangka Kasus Penyerangan}

Keterangan : Rabu, 03 Maret 2021 / 20.58 WIB

Analisis

Sintaksis

Lead berita yang digunakan langsung menyudutkan salah satu pihak. Pihak yang disudutkan oleh framing yang dibuat adalah Polri. Dengan menggunakan kalimat "Keenamnya telah tewas ditembak polisi. Mereka 
dijerat tersangka lantaran diduga menyerang anggota kepolisian”. Dari susunan kalimat tersebut yang diawali dengan "keenamnya telah tewas ditembak polisi" hal tersebut cenderung kesalahan berada di pihak Polri. Kemudian juga pihak Polri disudutkan dengan kalimat memberikan status tersangka kepada pihak FPI. Kutipan yang digunakan pada beriita ini hanya menggunakan pernyataan yang disampaikan oleh Direktur Tindak Pidana Kriminal Bareskrim Polri dan Komnas HAM.

Skrip

Penulis memberikan ruang lebih untuk menekankan apa yang sebenarnya terjadi. Yakni pernyataan yang berada di lead berita. Berita tersebut memberikan pernyataan bahwa ke enam laskar FPI ditembak polisi dan juga dijerat tersangka.

Tematik

Penyusunan isi berita dimulai dengan pernyataan paragraf pembuka bahwa polisi telah menembak keenam laskar FPI yang diduga juga menyerang anggota kepolisian. Secara singkat pernyataan tersebut disusun terpisah dengan paragraf lead sebelumnya. Sehingga fokus pembaca akan tertuju kepada paragraf tersebut. Pada paragraf selanjutnya penulis memberikan argumen pembanding bahwa penyematan tersangka kepada keenam laskar FPI tersebut dapat dikaji lebih lanjut. Akan tetapi, isi pada paragraf selanjutnya ditutup dengan kalimat "Namun demikian, kasus tersebut dapat dihentikan apabila memang Jaksa berpendapat lain" sehingga menunjukkan kasus tersebut. pada akhir penulisan, dijelaskan kembali tentang kejadian bentrok antara laskar FPI dan anggota Polri yang menewaskan enam orang laskar FPI. Ditambahkan juga pernyataan Komnas HAM untuk kedua pihak yakni bentrok tidak akan terjadi apabila laskar FPI tidak menunggu Polri yang menyudutkan pihak FPI dan penembakan terhadap 4 dari 6 laskar FPI merupakan perbuatan pelanggaran HAM yang menyudutkan pihak Polri.

Retoris

Penggunaan kata "tewas" dalam mengartikan korban 6 Laskar FPI. Kata tewas sendiri mempunyai kata lain seperti : mati, tewas, gugur, meninggal, terbunuh, menghembuskan nafas terakhir dan sebagainya (Eriyanto, 2002).

\section{Analisis Berita 6}

Judul

: Tiga Polisi Jadi Terlapor Kasus Unlawfull Killing Laskar FPI

Keterangan : Rabu, 03 Maret 2021 / 22.09 WIB

Analisis

Sintaksis

Penulisan pada pemberitaan ini menunjukan lebih menyudutkan ke salah satu pihak, yakni pihak Polri. Hal tersebut ditunjukan dengan menggunakan 
lead "Tiga personel kepolisian dari Polda Metro Jaya menjadi terlapor dalam penyelidikan kasus unlawfull killing peristiwa bentrok dengan laskar Front Pembela Islam (FPI) di Jalan tol Jakarta-Cikampek KM 50 pada akhir tahun lalu" yang berarti menekankan kepada pembaca bahwa personel dari kepolisian sudah melakukan unlawfull killing". Kemudian kutipan yang digunakan dari pihak Polri dan Komnas HAM.

Skrip

Penulisan pada berita ini dilakukan dengan memperluas porsi pada aspek apa (what). Yakni banyak menunjukan tentang peristwa unlawful killing yang dilakukan oleh pihak polisi. Walaupun terdapat juga bagian bagaimana proses yang akan dilakukan oleh pihak kepolisian.

Tematik

Penyusunan berita dapat dibagi menjadi 5 bagian. Dimulai dari lead berita yang menjelaskan tentang tiga personel kepolisian telah menjadi terlapor dalam proses penyelidikan unlawful killing. Kemudian berita disusun pada bagian kedua dengan proses yang sudah dilakukan pihak kepolisian yakni pihak polisi sudah membuat laporan polisi. Pada bagian ketiga, penulis menjelaskan kembali rangkaian peristiwa yang terjadi dalam bentrok di tol Jakarta- Cikampek KM 50 dengan membuat narasi polisi menembak mati laskar FPI karena melawan. Pada bagian keempat penulis menunjukan pernyataan dari Kapolri untuk melihat rekomendasi dari Komnas HAM. Pada bagian terakhir, masih mempunyai hubungan dengan paragraf selanjutnya dengan menambahkan narasi bahwa Komnas HAM menyatakan membunuh 4 dari 6 orang tersebut merupakan pelanggaran HAM dan merekomendasikan penegakan hukum dilanjutkan dengan mekanisme pidana.

Retoris

Kata "terlapor" pada lead menunjukan dan condong bahwa pihak kepolisian tengah menjadi pihak yang telah melakukan kejahatan. Pada berita ini juga terdapat infografis insiden penembakan versi Komnas HAM yang menunjukan pihak polisi melakukan pelaggaran HAM. Grafis tersebut juga untuk memperkuat kembali pernyataan Komnas HAM pada bagian paragraf sebelumnya.

Setelah melakukan analisis dari keseluruhan berita mengenai penembakan 6 Laskar FPI, CNN Indonesia lebih menekankan pada pihak korban, yang mana pada hal ini adalah pihak yang tertembak (pihak FPI). Dilihat dari sisi sintaksis yang banyak menekankan pada lead berita yang berfungsi menjadi prioritas utama dalam pemberitaan mengarah lebih memihak korban dan menyudutkan pihak Polri. Begitu pula ditekankan pada elemen tematik, yang mana penulis menyusun suatu berita dengan selalu menekankan 
kepada pernyataan Komnas HAM yang menyimpulkan pelanggaran HAM oleh pihak Polri. Namun cover bothside dalam penyusunan masih tetap dilakukan dan tidak terlalu jelas dalam menekankan kepada salah satu pihak.

CNN Indonesia selalu menggunakan kutipan dalam setiap paragraf berita yang disampaikannya, hal tersebut bertujuan untuk meyakinkan khalayak bahwa informasi tersebut valid bukan semata-mata berasal dari pandangan wartawan sendiri. Headline yang digunakan pada setiap berita mencerminkan dari isi berita dan selalu memperhatikan unsur berita yaitu $5 \mathrm{~W}+1 \mathrm{H}$. Dalam menyampaikan informasi, berita yang disampaikanya menampilkan isi yang lebih panjang, dalam artian berita tersebut mempunyai konteks, setiap berita tampil utuh, mengandung latar belakang dan untuk mengerti tujuan dari penyampaian berita tersebut. Hal ini sesuai dengan visi dan misi CNN Indonesia "panjang bukan berarti membosankan. Dan pendek bukan berarti dangkal. Kami tidak menjadi hakim. Tidak pula menjadi algojo. Niatan kami hanyalah mengungkapkan fakta secara apa adanya. Membilasnya dari bias (CNNIndonesia.com)". Maka hasil dari penelitian ini adalah CNN Indonesia tidak menggiring pembaca untuk memihak atau condong kepada salah satu pihak, tetapi membiarkan pembaca untuk melakukan pembentukan pandangan sendiri terhadap peristiwa yang di informasikannya.

\section{SIMPULAN DAN SARAN}

Media merupakan sarana bagi masyakat luas untuk menerima berbagai sumber infomasiDalam melakukan pembingkaian berita, CNN Indonesia selalu menggunakan kutipan dalam setiap paragraf berita yang disampaikannya, hal tersebut bertujuan untuk meyakinkan khalayak bahwa informasi tersebut valid bukan semata-mata berasal dari pandangan wartawan sendiri. Headline yang digunakan pada setiap berita mencerminkan dari isi berita dan selalu memperrhatikan unsur berita yaitu $5 \mathrm{~W}+1 \mathrm{H}$. Cnn Indonesia ketika menyampaikan informasi berita yang disampaikanya menampilkan isi yang lebih panjang, dalam artian berita tersebut mempunyai konteks, setiap berita tampil utuh, mengandung latar belakang dan untuk mengerti tujuan dari penyampaian berita tersebut. CNN Indonesia tidak menggiring pembaca untuk memihak atau condong kepada salah satu pihak, tetapi membiarkan pembaca untuk melakukan pembentukan pandangan sendiri terhadap peristiwa yang di informasikannya.Keterbatasan penelitian ini tidak menyertakan wawancara dalam proses pengambilan sumber data serta pengolahannya. Diharapkan penelitian selanjutnya dapat memberikan data yang lebih valid berupa hasil wawancara agar lebih memperkuat dari hasil penelitian tersebut. Hasil penelitian ini perlu dikembangkan lebih dalam, sehingga dapat 
menambah wawasan keilmuan mengenai pembingkaian media dalam menginformasikan berita terutama media yang ada di Indonesia.

Keterbatasan penelitian yaitu tidak menyertakan wawancara dalam proses pengambilan sumber data serta pengolahannya. Diharapkan penelitian selanjutnya dapat memberikan data yang lebih valid berupa hasil wawancara agar lebih memperkuat dari hasil penelitian tersebut. Hasil penelitian ini perlu dikembangkan lebih dalam, sehingga dapat menambah wawasan keilmuan mengenai pembingkaian media dalam menginformasikan berita terutama media yang ada di Indonesia

\section{DAFTAR PUSTAKA}

Arby, Ivany Atina. Bripka CS Pelaku Penembakan di Kafe RM Cengkareng Ternyata Naik Pitam saat Ditagih Rp 3,3 Juta.

https://megapolitan.kompas.com/read/2021/02/26/09411991/bripka-cspelaku-penembakandi-kafe-rm-cengkareng-ternyata-naik-pitam 26 Februari, 2021

Agustin, Risa. (2011). Kamus Lengkap Bahasa Indonesia. Serba Jaya: Surabaya. Mubahalah.

Ain, Dhf. Keluarga Laskar FPI Undang Kapolda Metro Sumpah

https://www.cnnindonesia.com/nasional/20210302090957-12-

612483/keluarga-laskarfpi-undang-kapolda-metro-sumpah-mubahalah 2 Maret, 2021

Sobur, Alex. (2015). Analisis teks media. PT. Remaja Rosdakarya: Bandung.

Amir, Ma'ruf. (1999). Etika Komunikasi Massa dalam Pandangan Islam. PT Logos Wacana Ilmu: Jakarta.

Arh, Mjo. Ditembak Mati, 6 Laskar FPI Jadi

Tersangka Kasus Penyerangan.

https://www.cnnindonesia.com/nasional/20210303205118-12-

613402/ditembak-mati-6laskar-fpi-jadi-tersangka-kasus-penyerangan 3 Maret, 2021

Arh, Mjo Rzr. Polri Cari Bukti Permulaan Unlawful

Killing $6 \quad$ Laskar FPI.

https://www.cnnindonesia.com/nasional/20210303174315-12-613321/polricari-buktipermulaan-unlawful-killing-6-laskar-fpi 3 Maret, 2021

Bmw, Mjo. Kabareskrim Baru Agus Andrianto Jamin

Kasus KM $50 \quad$ Tuntas.

https://www.cnnindonesia.com/nasional/20210219142718-12-

608393/kabareskrim-baruagus-andrianto-jamin-kasus-km-50-tuntas 19 februari, 2021

Bungin. (2006). Sosiologi Komunikasi Teori, Paradigma, dan Dikursus. Kencana Prenada Media Group: Jakarta. 
Eriyanto. (2002). Analisis Framing: Kontruksi, Ideologi, Dan Politik Media. PT. Lkis. Yogyakarta.

D’Elstason, Adolf Hitler. (2019). Kebijakan Redaksi Tv Program Cnn Indonesia Good Dalam Pemilihan Tayangan Berita. Skripsi. Universitas Prof. Dr. Moestopo, Jakarta.

Khatimah, Husnul. (2018). "Posisi Dan Peran Media Dalam Kehidupan Masyarakat.” Tasâmuh. Volume 16, No 1.

Harras, Kholid A. (2014). Membaca 1. In: Hakikat dan Proses Membaca. Jakarta: Universitas Terbuka.

Kahar, Azwar Marzuki. (2016). "Analisis Framing Rubrik Laporan Utama Tabloid Verbeek.” KAREBA. Vol 5, No 2.

Kid, Mjo. Kabareskrim Baru Ungkap Ada Kendala Tuntaskan Kasus KM 50. https://www.cnnindonesia.com/nasional/20210224191924-12610525/kabareskrim-baruungkap-ada-kendala-tuntaskan-kasus-km-50 24 Februari, 2021

Kusuma, Dedi. (2018). "Fungsi Media Massa. Jurnal Ilmu Komunikasi." Interaksi: Jurnal Ilmu Komunikasi. Vol 7, No 2.

Ningsih, Nonik Wahyu. (2013). "Analisis Framing Pemberitaan Penembakan Solikin di Harian Jawa Pos dan Duta Masyarakat." Jurnal EKomunikasi. Vol I, No 1.

Nugroho, Bimo. (1999). Politik Media Mengemas Berita. ISAI: Jakarta.

Nugroho, Catur. (2014). "Konstruksi Berita Kontroversi Rancangan Undang-Undang Keistimewaan Yogyakarta (Analisis Framing Pan Dan Kosicki Terhadap Berita Surat

Kabar Harian Kompas Dan Kedaulatan Rakyat Edisi Januari 2011-Maret 2011.” LONTAR: Jurnal Ilmu Komunikasi. Vol, 2 No 3.

Subandi. (2011). Ekonomi Pembangunan, CetakanKesatu. Alfabeta: Bandung.

Sudibyo, Agus. (1999). Citra Bung Karno, Analisis Berita Pers Orde Baru. Bigraf: Yogyakarta.

Ubay. 10 pengertian website menurut para ahli. http://www.seputarpendidikan.com ～/2016/02/10pengertian-website-menurutparaahli.html. 10 Juni 2016. 